\title{
Partial Replacement of Fine Aggregate by Glass Powder in Concrete
}

\author{
Suraj P Mishra, Kalpana D Thakur, Vicky N Gupta \\ Thakur College of Engineering \& Technology, \\ Mumbai, Maharashtra
}

\begin{abstract}
The concrete trade is one in every of the biggest customers of natural resources because of that property of concrete trade is underneath threat. The environmental and economic concern is that the biggest challenge the concrete trade is facing, the problems of environmental and economic concern are self-addressed by the utilization of waste glass as partial replacement of fine aggregates in concrete. Fine aggregates will be replaced by waste glass powder as $5 \%$, $10 \%, 15 \%, 20 \%$ and $40 \%$ weight for M-20 mix. The concrete specimens will be tested for compressive strength at 4,7 and 28 days respectively and also the results obtained will be compared with those of traditional concrete. Glass powder (GP) utilized in concrete creating ends up in the greener setting. In shops, broken glass sheets $\&$ flat solid cuttings are attending to waste, that aren't recycled at this time and typically delivered to landfills for disposal. Utilization in concrete is a motivating risk for the economy on waste disposal sites and conservation. This project examines the likelihood of utilization of GP in fine mixture replacement in concrete. Natural sand will be part replaced $(0 \%-40 \%)$ with GP in concrete. Compressive strength up to 28 days respectively will be compared with those of control mix created with natural sand.
\end{abstract}

\section{Keywords -Recycled, Brobdingnagian}

\section{INTRODUCTION}

In order to form concrete business property, the utilization of waste materials in situ of natural resources is one in every of the simplest approaches. A massive amount of waste glass is generated all round the world. In India, $0.7 \%$ of total urban waste generated includes of glass. GBP produces over 4 million heaps of waste glass annually. Waste glass is crushed into given sizes to be used as mixture in numerous applications like water filtration, grit application, sand protect sport turf and sand replacement in concrete. Concrete is most generally used imitation construction material and its demand is increasing day by day.

The utilization of watercourse sand as fine mixture ends up in exploitation of natural resources, lowering of formation, sinking of bridge piers and erosion of watercourse bed. If fine mixture is replaced by waste glass by specific share and in specific size vary, it'll decrease fine mixture content and thereby reducing the sick effects of watercourse dredging and so creating concrete producing business property. The number of waste glass created has bit by bit redoubled over the recent years because of associating ever growing use of glass product. Most waste glass has and is being drop into lowland sites.

\section{NEED OF THE PROJECT}

The land filling of waste glass is undesirable as a result of waste glass is nonperishable that makes them environmentally less friendly. Utilization of this waste is that would like of the hour. There's Brobdingnagian potential for utilization of waste enclose the concrete construction sector. Once waste glasses are reused in creating concrete product, the assembly price of concrete can go down. This move can serve 2 purposes.

- To judge the utility of glass powder as a partial replacement of cement in concrete.

- To check and compare the performance standard concrete and glass powder concrete.

- To know the effectiveness of glass powder in strength improvement.

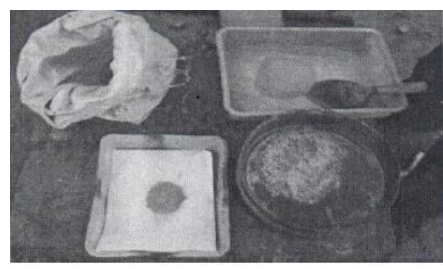

\section{METHODOLOGY \& EXPERIMENTAL INVESTIGATION}

\subsection{Material Used \\ 3.1.1 Cement, Water,Aggregate}

Concrete is prepared by mixing various materials like cement, Water, aggregates etc. which are economically available. IS 8112 is used for the work. The fine aggregate used in this investigation was clean river sand, whose maximum size is $4.75 \mathrm{~mm}$, conforming to grading zone II. Machine crushed blue granite stone is used as coarse aggregate . Two size of coarse is used; one $16 \mathrm{~mm}$ passing through $12.5 \mathrm{~mm}$ retained and other $25 \mathrm{~mm}$ passing through 20mm retained. As per IS: 2486 - 1964 recommendations the following properties of coarse aggregates were determined.

\subsubsection{Glass}

Waste glass is easily available in shops is collected and made glass powder.Before adding this glass material into concrete we have to crush it first into desired size.For study glass powder pulverized for 45 minutes and size less than $150 \mu \mathrm{m}$. 
The Physical,Chemical properties and chemical composition are presented in the table 3.1,3.2,3.3

\begin{tabular}{l|l}
\hline Property & Glass \\
\hline Density & $2380 \mathrm{~kg} / \mathrm{m} 3$ \\
Specific heat & $1235.08 \mathrm{~J} / \mathrm{kg} \cdot \mathrm{K}$ \\
Thermal conductivity & $2.1 \mathrm{~W} / \mathrm{m} \cdot \mathrm{K}$ \\
Dynamic viscosity & $600 \mathrm{~Pa} . \mathrm{s}$ \\
Latent heat & $205 \mathrm{~kJ} / \mathrm{kg}$
\end{tabular}

Table 3.1 Physical Property of Glass

\begin{tabular}{c|c} 
Quality & Value \\
\hline Hardness & $6-7$ in Mosh scale \\
\hline Bulk density & $1.5 \mathrm{~kg} / \mathrm{l}$ \\
\hline Color & white, green, brown \\
\hline Shape & Sharp-edged \\
\hline Smell & Neutral \\
\hline Softening $600^{\circ} \mathrm{C}$ \\
\hline Solubility in water & $\mathrm{n} / \mathrm{a}$ \\
\hline pH value in water & $<11$ \\
\hline Flammability & $\mathrm{n} / \mathrm{a}$ \\
\hline Explosiveness & $\mathrm{n} / \mathrm{a}$ \\
\hline Radioactivity & $\mathrm{n} / \mathrm{a}$
\end{tabular}

Table 3.2 Chemical Property of Glass

\begin{tabular}{|c|c|c|c|}
\hline Composition & Wt.\% & Composition & Wt.\% \\
\hline $\mathrm{Na}_{2} \mathrm{O}$ & 3.51 & $\mathrm{CeO}_{2}$ & 0.27 \\
\hline $\mathrm{S}$ & 0.054 & $\mathrm{Al}_{2} \mathrm{O}_{3}$ & 1.52 \\
\hline $\mathrm{Cr}_{2} \mathrm{O}_{3}$ & 0.009 & $\mathrm{CaO}$ & 1.32 \\
\hline $\mathrm{ZnO}$ & 0.52 & $\mathrm{Fe}_{2} \mathrm{O}_{3}$ & 0.42 \\
\hline $\mathrm{MoO}_{3}$ & 0.035 & $\mathrm{SrO}$ & 7.7 \\
\hline $\mathrm{Sb}_{2} \mathrm{O}_{3}$ & 0.49 & $\mathrm{CdO}$ & 0.016 \\
\hline $\mathrm{La}_{2} \mathrm{O}_{3}$ & 0.052 & $\mathrm{HfO}_{2}$ & 0.039 \\
\hline $\mathrm{MgO}$ & 0.57 & $\mathrm{SiO}_{2}$ & 54.1 \\
\hline $\mathrm{K}_{2} \mathrm{O}$ & 6.1 & $\mathrm{TiO}_{2}$ & 0.44 \\
\hline $\mathrm{MnO}$ & 0.012 & $\mathrm{NiO}$ & 0.011 \\
\hline $\mathrm{Ga}_{2} \mathrm{O}_{3}$ & 0.007 & $\mathrm{ZrO}_{2}$ & 2 \\
\hline $\mathrm{PdO}$ & 0.37 & $\mathrm{In}_{2} \mathrm{O}_{3}$ & 0.18 \\
\hline $\mathrm{BaO}$ & 9.4 & $\mathrm{PbO}$ & 10.9 \\
\hline
\end{tabular}

Table 3.3 Chemical Composition of Glass

\subsection{Methodology}

Cementations composites satisfy various civil engineering requirements such as high durability or impact load resistance. To study the behavior of reinforced concrete with different volume ratios, nearly 15 specimens were cast and tested for compressive test.

\subsection{Test}

\subsubsection{Tests on Cement}

In Cement, the tests conducted were:

1. Fineness test by sieve analysis

2. Standard consistency test using Vicat apparatus

3. Initial and final setting time by using Vicat apparatus

\subsubsection{Tests on Fine Aggregate}

1.Specific gravity

2.Sieve Analysis

\subsubsection{TEST ON FINAL PRODUCT:}

Testing of specimen
1) Casting detail of specimen

2) Compression test for glass powder mix concrete

\subsubsection{Compressive Strength Test}

For compression test, cube specimens of size $150 \mathrm{x} 150 \mathrm{x}$ $150 \mathrm{~mm}$ were cast for M40 grade of concrete. The moulds were filled with different proportions of cement, glass powder. Vibration was given to the moulds using table vibrator. The top surface of the specimen was leveled and finished. After 24 hours the specimens were demoulded and were transferred to curing tank wherein they were allowed to cure for 7,14,28 days. After 7,14,28 days of curing, these cubes were tested on compression testing machine as per I.S. 516-1959. The failure load was noted. The cubes were tested and their average value is reported. The formula used for compessive strength calculation:

Compressive strength $(\mathrm{MPa})=$ Failure load $/$ cross sectional area

\subsection{Experimental Investigation 3.4.1.Mix Proportion:}

The concrete mix design was proposed by using IS 10262 . M-20 concrete grade was used with water cement ratio of 0.45.The mixture proportions used in laboratory for experimentation are shown in the tables above.

\subsubsection{Test on Fresh Concrete}

The workability of all concrete mixtures was determined through slump test utilizing a metallic slump mold. The difference in level between the height of mold and that of highest point of the subsided concrete was measured and reported as slump. The slump tests were performed according to IS 1199-1959.

\subsubsection{Light Weight Character}

The average dry weight of concrete cube specimens containing $10 \%, 20 \%, 40 \%$ and $40 \%$ waste glass powder in place of fine aggregates was compared with average dry weight of normal M-25 concrete cube specimens and the percentage decrease in dry weight was measured.

\section{TEST RESULT AN DICUSSION}

The compressive test of concrete is tested,the below table shows compressive strength of cube.

\begin{tabular}{|c|c|c|c|c|}
\hline $\begin{array}{l}\mathrm{Sr} \\
\mathrm{N} \\
\mathrm{O}\end{array}$ & $\begin{array}{l}\% \\
\text { Replacme } \\
\text { nt }\end{array}$ & $\begin{array}{lr}4 & \text { Day } \\
\text { StrengthN/mm } \\
\wedge 2\end{array}$ & $\begin{array}{lr}7 & \text { Day } \\
\text { StrengthN/mm } \\
\wedge 2\end{array}$ & $\begin{array}{l}28 \text { Day } \\
\text { StrengthN/mm } \\
\wedge 2\end{array}$ \\
\hline 1 & 0 & 7.28 & 10.66 & 21.45 \\
\hline 2 & 10 & 10.85 & 12.44 & 19.22 \\
\hline 4 & 15 & 11.2 & 14.44 & 19.1 \\
\hline
\end{tabular}

Table 5.1: Comprssion Testing Results 


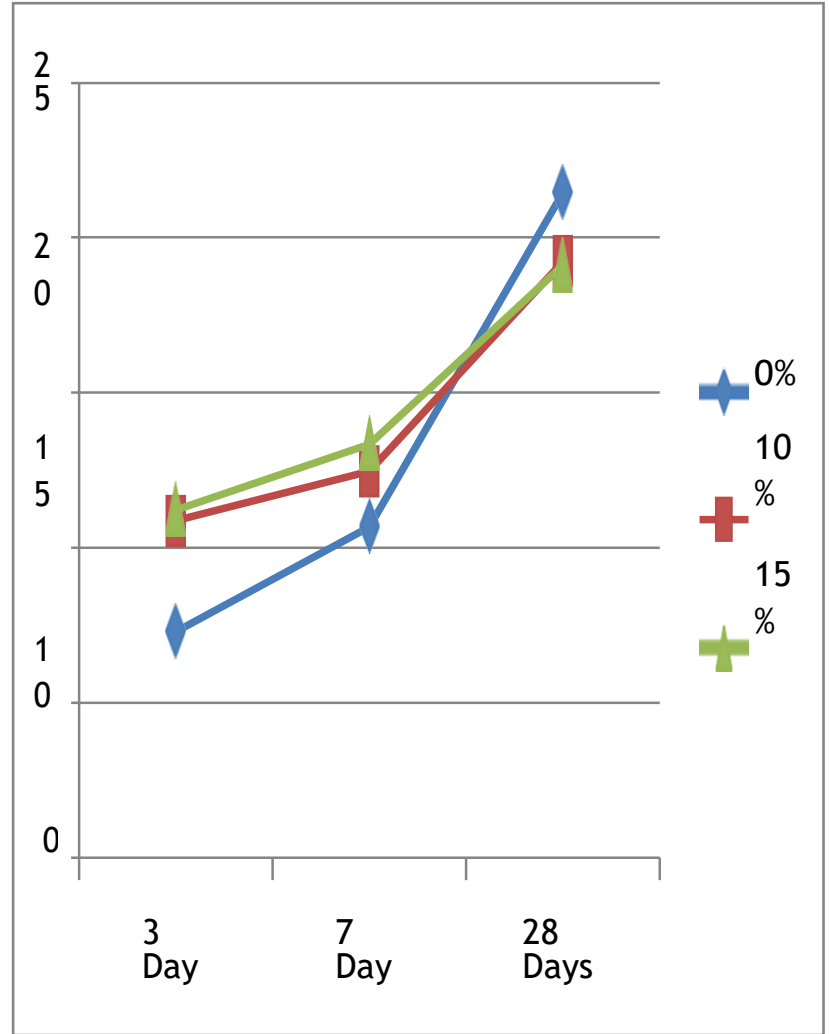

Graph 5.2:Copression Testing Result

\section{DISCUSSION}

The chemical compostion of normal glass and colored glass powders are quite similar and the materials could be declared as pozzolanic material as per ASTM standard. Being cleaner in nature, the flow of glass replaced mortar was found to be increased slightly with glass powder content. The optimum glass content is $15 \%$ after that strength start reducing. In 28 days the compressive strength was found slightly higher $(2 \%)$ than the control concrete specimen. In general, considering the similar performance with replaced material, glass addition can reduce cost of cement production up to $20 \%$. In addition, production of every six ton glass powder concrete results in the reduction of each ton $\mathrm{CO} 2$ emission from cement production and save the environment significantly by reducing green-house gas and particulate production.

\section{REFERENCE}

[1] Asoka Pappu, Mohini Saxena, and R. Shyan Asolekar, "Solid Waste Generation In India And Their Recycling Potential In Building Materials", Regional Research Institute (CSIR) and IIT Bombay, India.

[2] P Turgut and E.S. Yahlizade, "Research into Concrete Blocks with Waste Glass", International Journal of Civil and Environmental Engineering 1:4 2009.

[3] Carpenter, A. J. and Cramer, C.M, "Mitigation of ASR in pavement patch concrete that incorporates highly reactive fine aggregate", Transportation Research Record 1668, Paper No. 991087,pp. 60-67,1999.

[4] I. B. Topcu and M. Canbaz, "Properties of Concrete containing waste glass", Cement and Concrete Research, vol. 44, pp. 267274, Feb. 2004.

[5] A S Rossomagina, D V Saulin, and I S Puzanov, "Prevention of Alkali-Silica Reaction in Glass Aggregate Concrete”, pp-2, Perm State Technical University, Russia.

[6] V. Corinaldesi, G. Gnappi, G. Moriconi, and A. Montenero, "Reuse of ground waste glass as aggregate for mortars", Waste Management, vol.2, pp.197-201, Jan.2005.

[7] A. Shayan and A. Xu, "Value added utilization of waste glass in concrete", Cement and Concrete Research, vol-44, pp.81-89, Jan.2004.

[8] 44 Grade Ordinary Portland Cement - Specification. IS 8112:1989, Bureau of Indian Standards, New Delhi. 